\title{
Sexual Behaviour of Combative Athletes - Is There a Greater Risk?
}
Authors' contribution:
A) conception and design of the study
B) acquisition of data
C) analysis and interpretation of data
D) manuscript preparation
E) obtaining funding

\author{
Petr Vajda ${ }^{\mathrm{A}-\mathrm{D}}$, Zdenko Reguli $^{\mathrm{A}, \mathrm{C}, \mathrm{E}}$ \\ Masaryk University, Brno, Czech Republic
}

ABSTRACT

Athletes are often associated with a greater degree of risk behaviour. It also includes potentially dangerous sexual habits and behaviour, among other things. This study deals with sexual habits and behaviour of combative athletes. The research sample (n-65) consists of representatives of various combat sports and these representatives are categorized into three groups: international (n-15), national (n-28), and regional competitors (n-22). Data were collected through the medium of a questionnaire which allowed us to compare results with sexual behaviour of Czech population over last 20 years. Athletes comprised in this study are more sexually active, have more sexual partners over the life, and tend to have various, risk sexual behaviour more likely than common Czech population. This phenomenon is more significant in elite athletes. We believe this could be affected by access to short-term relationships and by the awareness of athletes that they are attractive to women. In the light of these findings, we suggest to increase prevention of risky sexual behaviour for athletes in masculine sports.

\section{KEYWORDS}

\section{Introduction}

Athletes are often associated with a greater degree of risk behaviour. It also includes potentially dangerous sexual habits and behaviour, among other things. Athletes in many cases tend to have more sexual partners and shorter-term relationships. It has been shown that athletes have statistically more sexual partners and sexual activities, by comparing students who participate in regular sports activities and their non-sports opposites (Grossbard, Lee, Neighbors, Hendershot, \& Larimer 2007; Wetherill \& Fromme 2007). It does not always concern both sexes, because it is possible to observe the opposite trend in female athletes. Female athletes often have less sexual activity and sex partners, or less often have multiple partners than their nonsports counterparts (Allison 2016; Habel, Dittus, De Rosa, Chung \& Kerndt 2010; Miller, Sabo, Farrell, Barnes \& Melnick 1998). Interesting are the results of a study held on a large group of students that shows greater use of condoms by athletes than non-athletes (Taliaferro, Rienzo \& Donovan 2010). In the light of this it is evident that athletes are not always or more frequently involved in all risky behaviour than non-athletes.

We assume that increased sexual activity of athletes may be partly due to easier access to sexual partners, especially to those who are interest in short-term relationship. While in the strategy of selecting long-term partners, future husbands and fathers, apart from health factors such as access to resources, social status (or resource holding potential for young men) are more important; in men-selection strategies which women do 
not expect to invest in their offspring, physical qualities, particularly testosterone and immune traits (physical symmetry, musculature, height, beard and hair density, triangular body shape, etc.) predominate. From behavioural characteristics, for example, bravery, courage, strength, fame, social visibility could be preferred. Men's success can be supported by sexual assertiveness, or a mild form of sexual aggression (Weiss 2010). Such men are more often chosen as extra partner outside of actual women's relationship (Puts 2010). We can assume that combat athletes will excel in many of mentioned characteristics. Number of short-term partners could be increased by masculinity and significant sexual dimorphism which are common in combat athletes (Rhodes, Simmons \& Peters 2005). Comparisons of masculine versus other sports, as well as contact versus non-contact sports showed that athletes in masculine and contact sports have more attractive (larger) facial width-to-height ratio (Kramer 2015). To sum up this information, athletes in combat sports probably have easier access to short-term or one night partners. This occasion could lead to higher rate of risk sexual behaviour.

Higher levels of testosterone are expected in a case of combative athletes due to the nature of the activity. These sports are not only likely to select individuals with higher levels of testosterone; but a form of exercise usual in their training can itself lead to elevated testosterone levels. It seems that speed, resistance, and strength training which are common in the training of those athletes can lead to increased testosterone secretion (Beaven, Gill, Ingram \& Hopkins 2011; Caruso et al. 2012; Kraemer et al. 1990; Lusa Cadore et al. 2009). However, it is not certain whether the levels rise chronically (Shariat, Shaw, Shaw \& Sadeghi 2015) Increased secretion may also occur in conjunction with pre-competition states (Salvador, Suay, González-Bono \& Serrano 2003).

The testosterone could be a predictor of potential risk behaviour. Hight testosterone levels in men could be connected with lower satisfaction from marriage, greater tendency to divorce, and lower a will to be in a marriage (Mazur \& Booth 1998). Men who leave a competitive mating environment and enter into a relationship with a permanent partner may experience a drop in testosterone. Conversely, those levels may increase during the divorce (Mazur \& Booth 1998). Overall, men with higher T levels may be less suitable for long-term relationships and they also feel lower satisfaction from being in one (Edelstein, van Anders, Chopik, Goldey \& Wardecker 2014).

Outside of sexual behavior, a testosterone level may affect the rate of risk acceptance or parental responsibility (Kuzawa, Georgiev, McDade, Bechayda \& Gettler 2016). It turned out that married fathers have less testosterone than single ones. Men with lower levels are rated better in paternal care. On the other hand, men with higher testosterone levels have a greater number of sexual partners over the time (Gray et al. 2017). The presence of attractive women or potential partners may lead to increased testosterone secretion and an increase will to accept a risk (J.R. Roney, Simmons \& Lukaszewski 2010; J.R. Roney, Lukaszewski \& Simmons 2007). These circumstances are very common in the modern concept of combative sports, e.g. "ring girls". It is assumed that not only the testosterone affects behaviour but there may also be an endocrine response of testosterone secretion to behaviour (Gray et al. 2017). It seems to work in both ways.

From these findings, it can be concluded that combative athletes may have a higher tendency to shortterm relationships, and they are more likely to break up long-term relationships.

\section{Research sample}

The research sample (n-65) consist of representatives of various combat sports. The representatives, ie. Athletes are categorized into three groups. The first group consists of international competitors (n-15), which includes 8 members of the Czech international representation team in their sports and 7 elite international athletes. Average length of the sports career of this group is $14.6 \pm 11.6$ years. The second and at the same the largest group consists of athletes competing at a national level (n-28) with a career duration of $7.54 \pm 5.27$ years. The last group consists of athletes competing at a lower level than national (regional or local) (n-22), but they also have extensive experience in combat sports and their career lasts for $8.05 \pm 9.73$ years. Athletes who are out of their prime are included in this last category, too. The sample was created by addressing numerous club's chief coaches, from the database of martial arts associations. However, the involvement of the clubs was very low. 


\section{Methods}

The questionnaire was sent to representatives of sports clubs and they distributed its copies to their athletes/respondets according to the instructions. Researchers never met the probands personally in order to ensure and keep absolute anonymity of the respondetns. A total of 69 responses was received, out of which 4 were rejected on the basis of incorrect or incomplete fulfilment. The used questionnaire is a very comprehensive tool that contained two parts. The first part was devoted to feeling the influence of sexual activity on sports performance and to changes of sexual habits during the period of increased training loads. This paper deals primarily with the other part, which is a short form of the questionnaire (Weiss \& Zverrina, 2001) which have been used since 1993 every 5 years to determine the state of the Czech population's sexual habits. The number of questions was reduced to 41 . This is a very complex tool for questioning sexual behaviour and habits, which allows to compare results of athletes in this sample with ordinary Czech men. MS Excel and Statistics 13 were used for statistical processing.

Table 1. Research sample characteristic

$\begin{array}{lll}\begin{array}{l}\text { Total sample } \\ (\mathrm{n}=65)\end{array} & \begin{array}{l}\text { International level } \\ \text { sample }(\mathrm{n}=15) \text { Mean }\end{array} & \begin{array}{l}\text { National level sample } \\ (\mathrm{n}=28) \text { Mean } \pm \mathrm{SD}\end{array} \\ \begin{array}{l}\text { Mean } \pm \mathrm{SD} \\ \text { or } \%\end{array} & \pm \text { SD or } \% & \text { or } \%\end{array}$

\begin{tabular}{|c|c|c|c|c|}
\hline & & & & r \% \\
\hline Age (years) & $26.93 \pm 7.5$ & $31.2 \pm 10.84$ & $25.54 \pm 3.87$ & $25.77 \pm 7.84$ \\
\hline $\begin{array}{l}\text { Carrer duration } \\
\text { (years) }\end{array}$ & $9.27 \pm 8,94$ & $14.6 \pm 11,6$ & $7.54 \pm 5.27$ & $8.05 \pm 9.73$ \\
\hline Sexualy active & $89 \%$ & $100 \%$ & $89 \%$ & $82 \%$ \\
\hline $\begin{array}{l}\text { Engaged in } \\
\text { relationship }\end{array}$ & $80 \%$ & $87 \%$ & $79 \%$ & $77 \%$ \\
\hline First coitus (years) & $17.05 \pm 1.97$ & $17.47 \pm 2.9$ & $16.93 \pm 1.68$ & $16.91 \pm 1.57$ \\
\hline $\begin{array}{l}\text { Number of sexual } \\
\text { partners (lifetime) }\end{array}$ & $10.73 \pm 9.15$ & $15.27 \pm 11.51$ & $11.39 \pm 9.34$ & $6.23 \pm 4.72$ \\
\hline
\end{tabular}

Source: Own study.

\section{Results}

The data got from the research sample coincide with the previously discovered trend of a higher number of sex partners in athletes. The average count of the sexual partners in the study group is $10.73 \pm 9.15$, this result is above average compared to the Czech population, which was reported in 9.4 partners (Weiss, 2012). Moreover, it is important to take into account the relatively low age of the addressed athletes $(26.93 \pm 7.5)$ years, which is probably much lower than the representative sample of the Czech population. This trend can be clearly traced to the number of partners $2.16 \pm 1.86$, that probands reported for the past year. There is a significant difference when compared to Czech population reported only 1.28 partners in the same period (Weiss, 2012). The research group also showed differences in the number of sexual partners among elite athletes and competitors at the regional/local level. There was no significant tendency in relation to age and number of sexual partners according to linear regression. The sexual debut of the sample is $17.05 \pm 1.97$ years, which is slightly lower than in the Czech population. This may also be due to the fact that when compared between generations, the young ones including our sample start their sexual life little earlier (Weiss, 2012). Only 4 athletes report that they exceeded the legal limit for the beginning of sexual life, which is 15 years of age in the Czech Republic.

\section{Sexual behaviour}

Combat athletes in the research sample show high level sexual activity. Sexual satisfaction from any source (masturbation or partner sexual practices) is reported $19.2 \pm 12.32$ per month. However, average need for sexual activity is only $18.06 \pm 9.82$. The discrepancy in answers also occurs at the sum of a high number of masturbation in the month of $14.98 \pm 12.33$ and the coitus with partner $9.38 \pm 8.52$. This sum of sexual 
activity (24) exceeds the reported total number. This variance may be caused by the difficulty of giving the exact number of sexual activity in the month. It is a great sexual activity compared to the Czech population data published by Weiss (2012). The research sample is almost three times more active in the case of masturbation and nearly twice as active as in partner sexual activities. Athletes who compete in lower than national level are slightly less sexually active than the more successful ones. The total sexual appetence is about twice as high as in a representative sample of Czech men. This may be partly influenced by the age of the research group.

Table 2. Level of sexual activity

$\begin{array}{llll}\begin{array}{l}\text { Total sample } \\ (\mathrm{n}=65) \text { Mean } \pm\end{array} & \begin{array}{l}\text { International level } \\ \text { sample }(\mathrm{n}=15) \text { Mean }\end{array} & \begin{array}{c}\text { National } \\ \text { level sample }(\mathrm{n}=28)\end{array} & \begin{array}{l}\text { Region } \\ \text { al/Local level }\end{array} \\ \mathrm{SD} & \pm \mathrm{SD} \text { or } \% & \text { Mean } \pm \text { SD or } \% & \text { sample }(\mathrm{n}=22) \\ \text { or } \% & & & \begin{array}{l}\text { Mean } \pm \text { SD } \\ \text { or } \%\end{array} \\ & & & \end{array}$

\begin{tabular}{lcccc}
\hline $\begin{array}{l}\text { Number sexual } \\
\text { satisfaction from any } \\
\text { source (number in } \\
\text { months) }\end{array}$ & $19.2 \pm 12.32$ & $17.8 \pm 8.91$ & $22.57 \pm 12.22$ & $16.14 \pm 14.02$ \\
$\begin{array}{l}\text { Sexual appetence } \\
\text { (number in months) }\end{array}$ & $18.06 \pm 9.82$ & $17.4 \pm 9.54$ & $19.68 \pm 9.58$ & $16.7 \pm 10.6$ \\
$\begin{array}{l}\text { Masturbation } \\
\text { (number in months) }\end{array}$ & $14.98 \pm 12.33$ & $13.13 \pm 9.15$ & $16.29 \pm 12.92$ & $14.59 \pm 15.73$ \\
$\begin{array}{l}\text { Intercourse (number } \\
\text { in months) }\end{array}$ & $9.38 \pm 8.52$ & $8,6 \pm 7.57$ & $11.68 \pm 10.22$ & $7 \pm 5.97$ \\
\hline
\end{tabular}

Source: Own study.

\section{Potentially risky sexual behaviour}

Experience with one night sexual partner was found in $78 \%$ of athletes. The average number of such partners per life is $6.29 \pm 7.4$. There is a clear trend between the athlete's level and the number of one night sexual partners, although it is a small research sample. Athletes at the regional/local level reported an average of only $3.75 \pm 3.44$ such partners. This can be easily explained by the above-mentioned views of the sex appeal of successful athletes. It can be assumed that elite athletes have easier access to sexual partners. Two-thirds $(66 \%)$ of probands used in intercourse with random sexual partners a condom which is the only effective protection against sexually transmitted diseases. This is a smaller part than in Czech population $88 \%$ (Weiss, 2012). Usage of a condom during the sexual debut is $48 \%$. The group of international athletes reported the smallest percentage of condom use (33\%). This value can be clearly explicated by an older age. There is an increasing trend of condom use in the Czech population. A great difference between the athletes' levels has been shown in the experience of commercial sex. The group of elite international athletes presented their experience in half of the cases. In contrast, a normal rate (ie. $14 \%$ for the national and $9 \%$ for the regional/local one) similar to Czech population turned out in other categories (Weiss, 2012). It seems, that there could be a link between a success in sport and the use of commercial sex, which is one of the risky sexual behaviour. Experience with sex-related illness was reported by top-level athletes only at $7 \%$, overall it was $9 \%$.

Table 3. Risky sexual behaviour and contraception usage

\begin{tabular}{lccc}
$\begin{array}{l}\text { Total sample } \\
(\mathrm{n}=65) \text { Mean } \pm \\
\text { SD } \\
\text { or } \%\end{array}$ & $\begin{array}{l}\text { International level } \\
\text { sample }(\mathrm{n}=15) \text { Mean } \\
\pm \text { SD or } \%\end{array}$ & $\begin{array}{c}\text { National } \\
\text { level sample }(\mathrm{n}=28) \\
\text { Mean } \pm \text { SD or } \%\end{array}$ & $\begin{array}{l}\text { Regio } \\
\text { nal/Local level } \\
\text { sample }(\mathrm{n}=22) \\
\text { Mean } \pm \text { SD } \\
\text { or } \%\end{array}$ \\
\hline $78 \%$ & $80 \%$ & $82 \%$ & $73 \%$ \\
$6.29 \pm 7,4$ & $9,5 \pm 11,3$ & $6,52 \pm 6,59$ & $3,75 \pm 3,44$
\end{tabular}




\begin{tabular}{|c|c|c|c|c|}
\hline $\begin{array}{l}\text { Currently active with } \\
\text { a one-night sex. } \\
\text { partners }\end{array}$ & $63 \%$ & $60 \%$ & $68 \%$ & $59 \%$ \\
\hline $\begin{array}{l}\text { Condom usage with a } \\
\text { one-night sex. partner }\end{array}$ & $66 \%$ & $67 \%$ & $59 \%$ & $69 \%$ \\
\hline \multicolumn{5}{|l|}{$\begin{array}{l}\text { Anticonception of } \\
\text { sexual debut } \\
\text { Contraception at the } \\
\text { sexual debut }\end{array}$} \\
\hline $\begin{array}{l}\text { Non or interrupted } \\
\text { coitus }\end{array}$ & $26 \%$ & $40 \%$ & $18 \%$ & $27 \%$ \\
\hline Condom & $48 \%$ & $33 \%$ & $54 \%$ & $50 \%$ \\
\hline $\begin{array}{l}\text { Hormonal } \\
\text { contraception }\end{array}$ & $26 \%$ & $27 \%$ & $29 \%$ & $23 \%$ \\
\hline $\begin{array}{l}\text { Experience of group } \\
\text { sexual activity }\end{array}$ & $22 \%$ & $27 \%$ & $25 \%$ & $14 \%$ \\
\hline $\begin{array}{l}\text { Experience of } \\
\text { commercial sex } \\
\text { Activity } \\
\text { Experience of }\end{array}$ & $20 \%$ & $47 \%$ & $14 \%$ & $9 \%$ \\
\hline $\begin{array}{l}\text { sexually transmitted } \\
\text { disease }\end{array}$ & $9 \%$ & $7 \%$ & $11 \%$ & $9 \%$ \\
\hline
\end{tabular}

\section{Discussion}

The study indicates increased sexual needs and activity in a group of combat athletes. These results are particularly valuable compared to the representative sample of the Czech population. Although athletes should be already included in population sample in the proportion in which they are found there. Sexual activity in the Czech Republic is generally higher than in other countries (Weiss \& Zvěřina, 2001). In addition to the mentioned factors that can influence sexual activity, the results have also shown that athletes feel less satisfied with sexual activities with their partners than with their relationship. They rated their relationship with an average mark of 2.26, but sexual activity with a long-term partner by 2.51 on scale from 1 to 6 , where 1 stands for very satisfied and 6 very dissatisfied. We believe that the access to short-term relationships can also be influenced by the awareness of athletes that they are attractive to women. This may naturally result in increased levels of self-confidence in attitude to women (Shavers et al., 2015).

In the risky behaviour, survey has shown a high level of experience with a one-night partner (78\%), beyond the number of short-term sexual partnerships. The experience with commercial sex is shown by $20 \%$ of the sample and $47 \%$ of men among the elite athletes. Compared to $14 \%$ of the Czech population, this is a significant difference (Weiss, 2010). There has also been a difference in experience of group sex.

\section{Conclusion}

As in previous studies investigating the sexual activity of athletes, the trend of more frequent, potentially dangerous sexual behaviour in a group of Czech combat athletes was revealed. We therefore consider appropriate to start perceiving athletes (specifically in masculine sports) as potentially more risky groups from this point of view. As the sources of sexual education are the same for athletes and non-athletes in the Czech Republic, the increased prevention is on the ground. The solution could be to start a state-supported prevention in sport clubs, as both subjects have a high interest in the athlete's health. 


\section{REFERENCES}

Allison, R. (2016). Gendered jocks or equal players? Athletic affiliation and hooking up among college students. Sociological Spectrum, 36(4), 255-270. https://doi.org/10.1080/02732173.2015.1123127

Beaven, C.M., Gill, N.D., Ingram, J.R. \& Hopkins, W.G. (2011). Acute salivary hormone responses to complex exercise bouts. Journal of Strength and Conditioning Research, 25(4), 1072-1078. https://doi.org/10.1519/JSC.0b013e3181bf4414

Caruso, J.F., Lutz, B.M., Davidson, M.E., Wilson, K., Crane, C.S., Craig, C.E., ... Potter, W.T. (2012). Salivary hormonal values from high-speed resistive exercise workouts. Journal of Strength and Conditioning Research, 26(3), 625-632. https://doi.org/10.1519/JSC.0b013e31822c7267

Edelstein, R.S., van Anders, S.M., Chopik, W.J., Goldey, K.L. \& Wardecker, B.M. (2014). Dyadic associations between testosterone and relationship quality in couples. Hormones and Behavior, 65(4), 401-407. https://doi.org/10.1016/j.yhbeh.2014.03.003

Gray, P.B., McHale, T.S. \& Carré, J.M. (2017). A review of human male field studies of hormones and behavioral reproductive effort. Hormones and Behavior, 91, 52-67. https://doi.org/10.1016/j.yhbeh.2016.07.004

Grossbard, J.R., Lee, C.M., Neighbors, C., Hendershot, C.S. \& Larimer, M.E. (2007). Alcohol and risky sex in athletes and nonathletes: what roles do sex motives play? Journal of Studies on Alcohol and Drugs, 68(4), 566-574.

Habel, M.A., Dittus, P.J., De Rosa, C.J., Chung, E.Q. \& Kerndt, P.R. (2010). Daily Participation in Sports and Students' Sexual Activity. Perspectives on Sexual and Reproductive Health, 42(4), 244-250. https://doi.org/10.1363/4224410

Kraemer, W.J., Marchitelli, L., Gordon, S.E., Harman, E., Dziados, J.E., Mello, R., ... Fleck, S.J. (1990). Hormonal and growth factor responses to heavy resistance exercise protocols. Journal of Applied Physiology, 69(4), 1442-1450.

Kramer, R.S.S. (2015). Facial Width-to-Height Ratio in a Large Sample of Commonwealth Games Athletes. Evolutionary Psychology, 13(1), 147470491501300. https://doi.org/10.1177/147470491501300112

Kuzawa, C.W., Georgiev, A.V., McDade, T.W., Bechayda, S.A. \& Gettler, L.T. (2016). Is There a Testosterone Awakening Response in Humans? Adaptive Human Behavior and Physiology, 2(2), 166-183. https://doi.org/10.1007/s40750-0150038-0

Lusa Cadore, E., Lhullier, F.L.R., Arias Brentano, M., Marczwski Da Silva, E., Bueno Ambrosini, M., Spinelli, R., ... Martins Kruel, L. F. (2009). Salivary hormonal responses to resistance exercise in trained and untrained middle-aged men. Journal of Sports Medicine and Physical Fitness, 49(3), 301-307.

Mazur, A. \& Booth, A. (1998). Testosterone and dominance in men. Behavioral and Brain Sciences, 21(03). https://doi.org/10.1017/S0140525X98001228

Miller, K.E., Sabo, D.F., Farrell, M.P., Barnes, G.M. \& Melnick, M. J. (1998). Athletic Participation and Sexual Behavior in Adolescents: The Different Worlds of Boys and Girls. Journal of Health and Social Behavior, $39(2), 108$. https://doi.org/10.2307/2676394

Puts, D.A. (2010). Beauty and the beast: mechanisms of sexual selection in humans. Evolution and Human Behavior, 31(3), 157-175. https://doi.org/10.1016/j.evolhumbehav.2010.02.005

Rhodes, G., Simmons, L.W. \& Peters, M. (2005). Attractiveness and sexual behavior: Does attractiveness enhance mating success? Evolution and Human Behavior, 26(2), 186-201. https://doi.org/10.1016/j.evolhumbehav.2004.08.014

Roney, J.R., Simmons, Z.L. \& Lukaszewski, A.W. (2010). Androgen receptor gene sequence and basal cortisol concentrations predict men's hormonal responses to potential mates. Proceedings of the Royal Society B: Biological Sciences, 277(1678), 57-63. https://doi.org/10.1098/rspb.2009.1538

Roney, J.R., Lukaszewski, A.W. \& Simmons, Z.L. (2007). Rapid endocrine responses of young men to social interactions with young women. Hormones and Behavior, 52(3), 326-333. https://doi.org/10.1016/j.yhbeh.2007.05.008

Salvador, A., Suay, F., González-Bono, E., \& Serrano, M.A. (2003). Anticipatory cortisol, testosterone and psychological responses to judo competition in young men. Psychoneuroendocrinology, 28(3), 364-375. https://doi.org/10.1016/S03064530(02)00028-8

Shariat, A., Shaw, I., Shaw, B.S. \& Sadeghi, H. (2015). Analysis of the effects of resistance training on circadan rhythm of endocrine hormones. Russian Open Medical Journal, 4(3), e0302. https://doi.org/10.15275/rusomj.2015.0302

Shavers, T., Baghurst, T. \& Finkelstein, M. (2015). The Influence of Social Status and Power on the Sexual Behavior of Male Collegiate Football Athletes. Journal for the Study of Sports and Athletes in Education, 9(2), 86-101. https://doi.org/10.1179/1935739715Z.00000000037

Taliaferro, L.A., Rienzo, B.A. \& Donovan, K.A. (2010). Relationships between youth sport participation and selected health risk behaviors from 1999 to 2007. The Journal of School Health, 80(8), 399-410. https://doi.org/10.1111/j.1746- 


\subsubsection{0.x}

Weiss, P. (2010). Sexuologie. Praha: Grada.

Weiss, P. (2012, December 12). Sexuální chováni a sexuální postoje obyvatelstva České republiky: Výsledky reprezentativnich výzkumi. Praha. Retrieved from http://www.avcr.cz/opencms/export/sites/avcr.cz/cs/proverejnost/.content/soubory/dsc-teze/weiss-teze.pdf

Weiss, P., \& Zvěřina, J. (2001). Sexuální chováni v ČR: situace a trendy (Vyd. 1). Praha: Portál.

Wetherill, R.R. \& Fromme, K. (2007). Alcohol Use, Sexual Activity, and Perceived Risk in High School Athletes and Non-Athletes. Journal of Adolescent Health, 41(3), 294-301. https://doi.org/10.1016/j.jadohealth.2007.04.019

AUTHOR'S ADDRESS: Petr Vajda

Masaryk University, Faculty of Sport Studies

Kamenice 5, 62500 Brno

Czech Republic

Slovenia

E-mail: 380716@mail.muni.cz

Received: 26 February; Accepted: 16 April 2018 